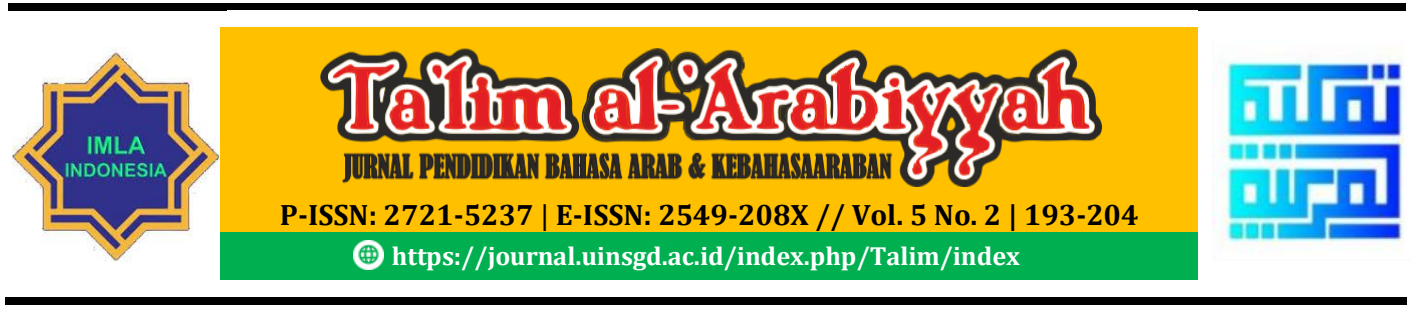

\title{
Kebutuhan Pengembangan Media Pembelajaran iSpring Suite Berbasis Android Pada Mata Pelajaran Morfologi Bahasa Arab
}

\author{
Vera Fikrotin ${ }^{1}$, Siti Sulaikho ${ }^{2}$ \\ 1,2Universitas KH. A. Wahab Hasbullah, Indonesia \\ Corresponding email: verafikrotin@gmail.com
}

\begin{abstract}
Learning media is an important component so that teaching and learning activities in class are carried out correctly. They are learning media as a means or intermediary tool to convey messages in the form of learning. This study aims to determine the needs of students in learning media Shorof. Where the effective media is the media according to the needs of students. The researcher uses the R\&D method with a 4D Thiagarajan model, which consists of defining, planning, developing, and disseminating. In collecting data, the researchers conducted observations and gave questionnaires to students' media needs. The average results show that students need learning media that can be accessed at any time to increase enthusiasm for learning in class VIII A with a percentage value of $79.00 \%$ (required) and class VIII B with a percentage value of $83.00 \%$ (required). The results of the percentage value state that students need an Android-based ispring suite learning media on shorof subjects because it can be accessed anytime.
\end{abstract}

Keyword: Learning Media, Ispring Suite, Android, Shorof

\section{ABSTRAK}

Media pembelajaran merupakan komponen penting agar proses kegiatan belajar mengajar dikelas terlaksana dengan baik. Media pembelajaran sebagai sarana atau alat perantara agar dapat menyampaikan pesan berupa pembelajaran. Penelitian ini bertujuan untuk mengetahui kebutuhan siswa terhadap media pembelajaran Ispring Suite pada mata pelajaran shorof. Peneliti menggunakan metode R\&D dengan model 4D dalam penelitian ini yang terdiri dari pendefinisian (define), perencanaan (design), pengembangan (development) dan penyebaran (dissemation). Pada pemerolehan data peneliti melakukan observasi dan pemberia angket kebutuhan media terhadap siswa. Hasil rata-rata menunjukkan bahwa siswa membutuhkan media pembelajaran yang dapat diakses kapanpun untuk meningkatkan antusias belajar pada kelas VIII A dengan nilai presentase $79.00 \%$ (dibutuhkan) dan kelas VIII B dengan nilai presentase $83.00 \%$ (sangat dibutuhkan). Hasil dari nilai presentase tersebut menyatakan bahwa siswa membutuhkan media pembelajaran ispring suite berbasis android pada mata pelajaran shorof karena dapat diakses kapanpun.

Kata Kunci: Media Pembelajaran, Ispring Suite, Android, Shorof 
Ta'lim al-'Arabiyyah : Jurnal Pendidikan Bahasa Arab dan Kebahasaaraban, 5 (2), 2021

\section{PENDAHULUAN}

Media pembelajaran memiliki peran yang begitu penting dalam menunjang proses belajar mengajar di dalam kelas maupun secara mandiri. Menurut Danim keberadaan media pembelajaran sangat efektif untuk membantu siswa dalam belajar serta menjadikan prestasi siswa lebih baik. Keberadaan media pembelajaran sangat membantu penyampaian pesan atau pembelajaran terhadap siswa. Media pembelajaran yang efektif dan efisien akan menjadikan pembelajaran dikelas berhasil. Sehingga jika media pembelajaran di dalam kurang efektif atau sesuai dengan kebutuhan siswa maka akan menjadikan siswa kurang minat dalam belajar mata pelajaran tersebut (Mahnun, 2012).

Menurut bahasa media merupakan perantara. Dalam bahasa latin media berasal dari kata "medius" yang memiliki arti perantara atau pengantar. Menurut Dina Indriana bahwa media menjadi salah satu perantara yang menjadikan proses belajar mengajar di dalam kelas terlaksana dengan baik (Nurrita, 2018). Saat guru melakukan kegiatan belajar mengajar di dalam kelas diperlukan sebuah media agar siswa mudah untuk memahami mata pelajaran tersebut. Tentunya media tersebut sesuai dengan kebutuhan siswa. Agar guru memperoleh media yang efektif maka perlu untuk memperhatikan media yang dibutuhkan siswa pada mata pelajaran tersebut. Semakin efektifnya media pembelajaran maka siswa akan mudah untuk memahami materi yang disampaikan.

Media pembelajaran memiliki fungsi sebagai perangsang siswa agar tertarik untuk belajar dan mempermudah dalam memahami (Falahudin, 2014). Bisa di pahami bahwa proses pembelajaran di dalam kelas merupakan suatu interaksi antara guru dengan siswa yang di antara itu harus ada respon atau timbal balik yang menandakan siswa itu faham pada pelajaran tersebut. Disini respon siswa sangat berarti untuk mengetahui keberhasilan pembelajaran tersebut. Respon bisa berupa pertanyaan atau hasil belajar yang maksimal. Oleh karena itu, agar pesan atau materi yang di sampaikan guru di cerna dengan mudah oleh siswa dengan adanya media pembelajaran.

Penggunaan media pembelajaran bertujuan agar pembelajaran terlaksana secara interaktif antara guru dan siswa. Media memiliki karakteristik yang perlu diketahui yaitu sebagai penyalur sekaligus terdapat informasi yang membantu seseorang. Menurut Kemp dan Dayton dalam Iwan Falahuddin memberi penjelasan tentang media yang memiliki kefesien pada waktu serta penggunaannya. Dikatakan media jika media tersebut mengatasi keterbatasan waktu dan ruang serta menjadikan sesuatu yang tidak nyata menjadi nyata atau konkret (Budiyono, 2020). Terkadang siswa belum cukup jika hanya belajar di kelas saja. Namun, siswa juga perlu belajar secara mandiri dirumah. Media yang bisa mengatasi keterbatasan waktu dan ruang akan menjadikan siswa mudah untuk mengakses media tersebut dan dipergunakan untuk belajar. Sehingga siswa akan mudah untuk memahami materi yang sebelumnya belum jelas dikelas atau memperdalam materi yang sebelumnya. Media pembelajaran memiliki fungsi bagi guru yaitu agar memvisualisasikan sesuatu yang abstrak menjadi konkret atau yang tidak nyata menjadi nyata. 
Dalam hal ini seiring dengan perkembangan teknologi yang semakin canggih dan memudahkan segala aktivitas dalam kehidupan manusia. Pendidikan di Indonesia tak boleh ketinggalan pembelajaran yang berbasis teknologi. Mengingat segala aktivitas hampir semuanya berhubungan dengan teknologi. Oleh karena itu, pentingnya melakukan pengembangan media pembelajaran guna menjadikan sarana belajar yang memudahkan bagi siswa. Selain itu, banyak siswa yang sekarang sudah memiliki smartphone. Smartphone merupakan handphone cerdas yang berbasis android. Pada awalnya keberadaan smartphone masih belum canggih seperti saat ini. Dari zaman ke zaman smartphone mendapatkan sebuah perubahan yang semakin sempurna. Bukan hanya untuk menjadi alat komunikasi saja tapi fungsi smartphone mampu untuk di isi dengan berbagai aplikasi (Ramadani, 2020). Mulai dari aplikasi jual beli, informasi, komunikasi yang mampu menembus penjuru dunia hingga edukasi. Tentunya ini menjadi alternatif agar pembelajaran juga bisa dipelajari melalui smartphone. Dengan menggunakan smartphone media pembelajaran bisa diakses siswa kapan pun. Baik menggunakan data atau tidak menggunakan data. Sehingga siswa akan mudah untuk belajar secara bersama atau mandiri.

Mata pelajaran shorof merupakan pembelajaran yang bisa dibilang sulit oleh sebagian siswa yang belum belajar atau pernah belajar. Shorof atau di sebut dengan morfologi termasuk ilmu yang membahas tentang perubahan pola kata dalam bahasa Arab. Menurut etimologi, shorof memiliki arti perubahan (Sulaikho, 2021). Sedangkan menurut terminologi shorof merupakan ilmu cabang dalam tata bahasa Arab yang di dalamnya membahas perubahan pola kata sehingga mengetahui kata dasar terhadap kata tersebut (Naseha \& Muassomah, 2018). Ruang lingkup shorof yang terdiri dari isim mutamakekin (isim yang bisa berubah -ubah atau mu'rob) dan fi'il mutasarrif (kata kerja yang dapat di tashriff. Tentunya dalam mempelajari materi tersebut dibutuhkan penyampaian yang mudah untuk di pahami siswa.

Seiring dengan perkembangan zaman media pembelajaran yang dibutuhkan siswa saat ini adalah media pembelajaran yang interaktif dan efisien serta bisa diakses kapan pun. Apalagi jika media pembelajaran di dalamnya menyenangkan serta memudahkan siswa dalam memahami materi tersebut. Jika mata pelajaran shorof terkenal sulit pada kalangan siswa. Maka bisa dicoba untuk mencari media pembelajaran yang interaktif dan menarik. Supaya siswa tidak hanya monoton pada metode hafalan serta pembelajaran dikelas saja. Karena selama ini pembelajaran shorof hanya monoton pada media pembelajaran buku dan hafalan. Sehingga sangat kurang efektif jika tidak dikembangkan dengan apa yang dibutuhkan siswa sekarang.

Media pembelajaran yang interaktif serta berbasis android bisa dibuat dengan mengembangkan media presentasi pada Microsoft iSpring Suite (PPT) menjadi flash kemudian dioleh menjadi aplikasi yang bisa diakses pada smartphone. Smartphone merupakan handphone cerdas yang bisa di isi dengan bermacam-macam fitur aplikasi mulai dari aplikasi yang berisi informasi, komunikasi, edukasi dan permainan. Kebanyakan siswa menggunakan smartphone sebagai media permainan dan komunikasi. 
Dalam hal ini media pembelajaran akan meningkatkan prestasi siswa jika media tersebut menarik dan memudahkan pemahaman siswa, menambah minat siswa serta efesien dalam penggunaannya (Nurrita, 2018). Media pembelajaran ispring suite berbasis android akan menjadikan pembelajaran shorof menjadi pembelajaran yang menyenangkan. Karena di dalamnya akan terdapat beberapa animasi, video, game serta kuis dan penjelasan materi yang bisa dikemas dengan menarik.

Pada zaman era teknologi yang canggih ini, guru tidak lagi hanya menggunakan media yang menjadikan pembelajaran monoton. Perlu di usahakan untuk memanfaatkan teknologi yang ada menjadi media pembelajaran yang dibutuhkan generasi saat ini. Oleh karena itu memasukan materi shorof kedalam media pembelajaran ispring suite berbasis android menjadikan media yang dibutuhkan siswa. Karena selain pembelajaran shorof yang masih menggunakan metode sorogan atau hafalan dan penjelasan dari referensi kitab bisa di kembangkan menjadi aplikasi yang dapat di operasikan pada smartphone.

Peneliti melakukan penelitian terhadap anak kelas VIII MTs Walisongo. Dengan melakukan observasi dan penyebaran angket kebutuhan terhadap siswa sehingga peneliti akan mengetahui kebutuhan media pembelajaran yang di butuhkan siswa.

\section{METODE}

Dalam penelitian ini, peneliti menggunakan metode research and development (R\&D). Suhadi Ibnu memberikan penjelasan mengenai penelitian pengembangan sebagai jenis penelitian untuk menghasilkan produk yang berupa hardware atau software yang kemudian di evaluasi (Purnama, 2013). Menurut Sugiyono, metode research and development adalah penelitian yang dilakukan untuk menghasilkan produk melalui beberapa tahap kemudian di uji keefektivannya (Sugiyono, 2019). Di dalam metode ini akan menghasilkan sebuah produk dan diuji akan kefektifan produk tersebut. Penelitian ini menggunakan model 4D Thiagarajan yang terdiri dari Pendefinisia (Define), Perencanaan (Design), Pengembangan (Develop), dan Penyebaran (Disseminate).

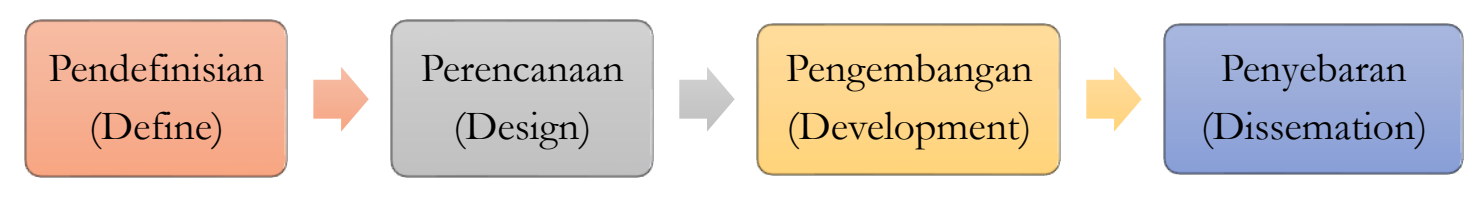

Model 4D Thiagaran merupakan salah satu model metode r\&d yang digunakan untuk menghasilkan sebuah produk. Model 4D ini terdiri dari pendefinisian (Define), perencanaan (Design), Pengembangan (Development) dan penyebaran (Dissemation). 
Pada tahap pertama, penulis melakukan pendefinisian (Define) melalui observasi dan wawancara. Peneliti melakukan observasi di dalam kelas untuk memperoleh data berupa kebutuhan media yang dibutuhkan siswa pada mata pelajaran shorof. Kemudia peneliti juga melakukan wawancara terhadap guru mata pelajaran shorof akan materi shorof.

Setelah mengetahui kebutuhan siswa akan media yang dibutuhkan. Peneliti melakukan tahap perencanaan (Design). Pada tahap ini, peneliti membuat rancangan awal atau pemilihan media yang sesuai dengan kebutuhan siswa. Setelah itu, peneliti melakukan tahap pengembangan (Development). Pada tahap ini, dilakukan pengembangan media pembelajaran ispring suite dengan berbasis android. Dan pada tahap ini juga di lakukan uji validasi pada produk oleh tiga ahli yang terdiri dari ahli materi, ahli media dan ahli bahasa. Kemudian ada beberapa revisi pada media. Setelah media di nyatakan valid dan boleh digunakan untuk uji coba. Maka tahap selanjutnya adalah tahap penyebaran (Dissemation). Media yang telah valid akan di sebarkan untuk uji coba.

Penelitian dilakukan pada kelas VIII MTs Walisongo Sugihwaras. Dalam pelaksanaannya, peneliti melakukan survey terhadap siswa dengan memberikan angket kebutuhan. Kelas VIII terbagi menjadi dua kelas yaitu kelas VIII A dan kelas VIII B.

Dalam mengolah data yang telah diperoleh, penelitian ini memakai rumus persentase di bawah ini:

$$
x i=\frac{\sum s}{S_{\max }} \times 100 \%
$$

Ket :

$\mathrm{S}_{\max } \quad=$ Skor maksimal yang terdapat pada instrument

$\sum S \quad=$ Jumlah skor / nilai yang diperoleh

$x i=$ Nilai kelayakan pada tiap aspek dalam instrument

Adapun hasil persentase yang dihasilkan kemudian dikelompokkan berdasarkan skala Likert 5 tingkat

Tabel 2. Skala Kelayakan Media Pembelajaran

\begin{tabular}{cc}
\hline Skor Presentase & Standar \\
\hline $81 \%-100 \%$ & Sangat Dibutuhkan \\
$61 \%-80 \%$ & Dibutuhkan \\
$41 \%-60 \%$ & Cukup Dibutuhkan \\
$21 \%-40 \%$ & Kurang Dibutuhkan \\
\hline
\end{tabular}


Dari tabel 2 di atas, akan diketahui standar kelayakan dari media pembelajaran yang dihasilkan. Jika hasil skor persentase menunjukan $\mathrm{X}>81 \%$, media tersebut dikatakan "Sangat Layak". Jika hasil skor persentase menunjukan $61 \%<\mathrm{X} \leq 80 \%$, media dikatakan "Layak". Jika hasil skor persentase menunjukan $41 \%<\mathrm{X} \leq 60 \%$, media tersebut dikatakan "Kurang Layak". Jika hasil skor persentase menunjukan 21\% $<\mathrm{X} \leq 40 \%$, media tersebut dikatakan "Kurang Layak". Jika hasil skor persentase menunjukan $\mathrm{X}<20 \%$, media tersebut dikatakan "Sangat Kurang Layak". Media akan disebarkan jika dari masing-masing ahli validator memberikan penilaian dengan hasil persentase yang masuk pada standar "Layak" atau "Sangat Layak".

\section{HASIL DAN PEMBAHASAN}

Berdasarkan hasil observasi yang dilakukan peneliti di MTs Walisongo Sugihwaras bahwa media yang digunakan pada mata pelajaran shorof masih berupa buku. Dan metode yang di lakukan saat pembelajaran yaitu dengan menghafal. Banyak anggapan bahwa shorof merupakan ilmu yang sulit untuk dipahami. Selain itu banyaknya siswa yang sudah memiliki smartphone menjadi alternatif sarana pembelajaran yang bisa di akses kapan saja. Karena smartphone merupakan handphone cerdas yang bisa di isi berbagai fitur aplikasi dengan masing-masing fungsinya.

Setelah peneliti melakukan observasi di dalam kelas VIII A dan kelas VIII B. Hasil observasi pembelajaran mata pelajaran shorof dikelas sebagai berikut.

\begin{tabular}{c|l}
\hline No & \multicolumn{1}{c}{ Hasil Observasi } \\
\hline 1 & Siswa masih belum memahami shorof dengan mudah \\
2 & Anggapan bahwa shorof adalah ilmu yang sulit \\
3 & Media pembelajaran masih berfokus pada buku \\
4 & Pembelajaran dikelas masih monoton dengan hafalan \\
5 & Waktu pembelajaran yang hanya berdurasi 20 menit di saat pandemic \\
\hline
\end{tabular}

Langkah selanjutnya peniliti menyebarkan angket kebutuhan siswa. Di harapkan siswa mengisi sesuai dengan kebutuhan media yang dibutuhkan. Angket kebutuhan berupa pernyataan. Berikut ini angket kebutuhan siswa yang disebarkan.

\begin{tabular}{cll}
\hline No. & \multicolumn{1}{c}{ Kriteria } & Skor \\
\hline 1. & Sumber belajar berupa buku/LKS dirasa sudah cukup & \\
2. & Antusias selama mengikuti pelajaran \\
3. & Termotivasi selama mengikuti pelajaran \\
4. & Materi pelajaran mudah dipahami & \\
\hline
\end{tabular}


Ta'lim al-'Arabiyyah : Jurnal Pendidikan Bahasa Arab dan Kebahasaaraban, 5 (2), 2021

5. Mengalami kesulitan dalam mempelajari materi
pelajaran yang hanya bersumber pada buku/LKS
6. Membutuhkan media pembelajaran yang dapat
bergerak untuk meningkatkan motivasi belajar
7. Membutuhkan media pembelajaran yang berwarna-
warni untuk meningkatkan antusias belajar
8. Membutuhkan media pembelajaran yang berisi video
9. Membutuhkan media pembelajaran yang dapat diakses
kapanpun untuk meningkatkan antusias belajar
10. Membutuhkan media pembelajaran yang dapat
menyajikan materi pelajaran secara menarik untuk
meningkatkan motivasi belajar

Para siswa mengisi angket di atas dengan skor 30 hingga 90. Kelas VIII terbagi menjadi dua kelas yaitu kelas VIII A dan kelas VIII B. Dari hasil angket kebutuhan siswa akan media pembelajaran shorof di gambarkan pada tabel dibawah ini.

a. Kelas VIII A

Tabel 2. Hasil Rata-rata Angket Kebutuhan Siswa (Butir 1-5)

\begin{tabular}{ccccc}
\hline Butir 1 & Butir 2 & Butir 3 & Butir 4 & Butir 5 \\
\hline $68.78 \%$ & $63.78 \%$ & $67.86 \%$ & $63.27 \%$ & $67.11 \%$ \\
\hline
\end{tabular}

Tabel 3. Hasil Rata-rata Angket Kebutuhan Siswa (Butir 6-10)

\begin{tabular}{ccccc}
\hline Butir 6 & Butir 7 & Butir 8 & Butir 9 & Butir 10 \\
\hline $74.02 \%$ & $77.32 \%$ & $77.02 \%$ & $79.00 \%$ & $76.39 \%$ \\
\hline
\end{tabular}


Ta'lim al-'Arabiyyah : Jurnal Pendidikan Bahasa Arab dan Kebahasaaraban, 5 (2), 2021

Hasil angket kebutuhan jika digambarkan dengan grafik sebagai berikut.

Grafik 1. Hasil Angket Kebutuhan Siswa

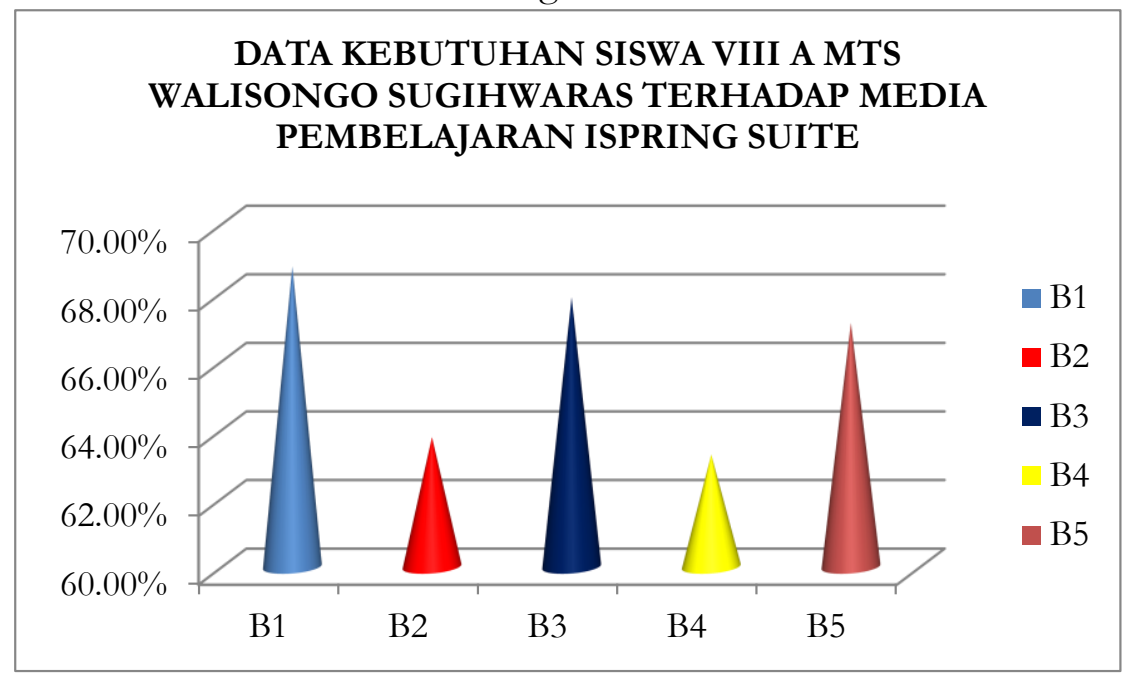

Grafik 2. Hasil Angket Kebutuhan Siswa

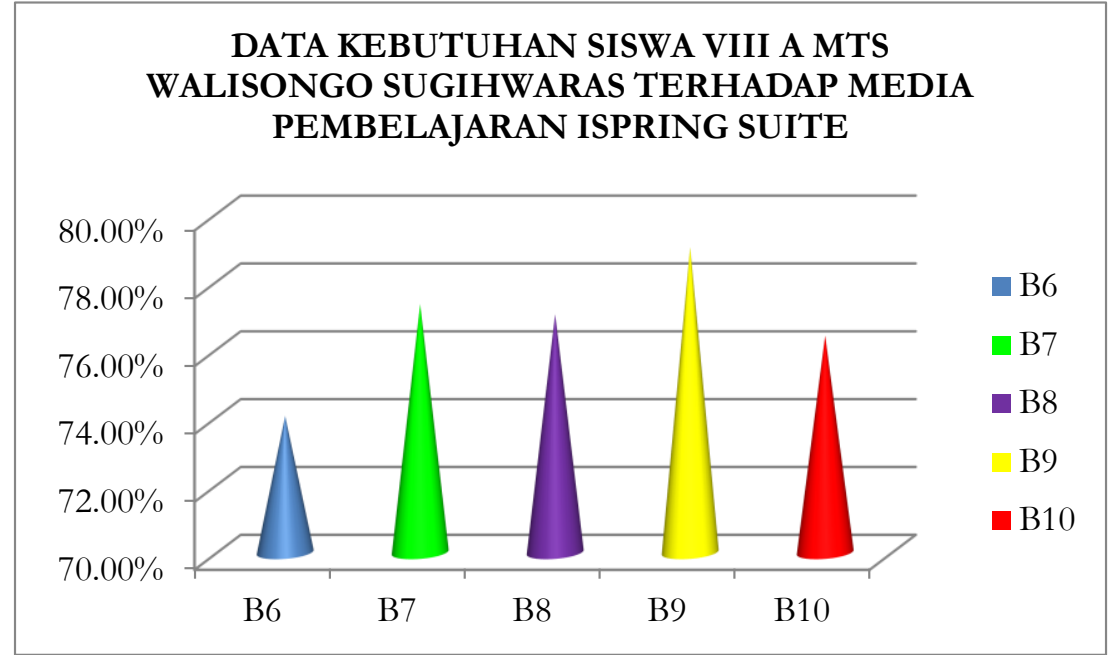

Dari data kebutuhan siswa kelas VIII A menunjukkan bahwa Sumber belajar berupa buku/LKS dirasa sudah cukup dengan nilai rata-rata 68.76\%, Antusias selama mengikuti pelajaran dengan nilai rata-rata $63.78 \%$, Termotivasi selama mengikuti pelajaran dengan nilai rata-rata $67.86 \%$, Materi pelajaran mudah dipahami dengan nilai rata-rata $63.27 \%$, Mengalami kesulitan dalam mempelajari materi pelajaran yang hanya bersumber pada buku/LKS dengan nilai rata-rata 67.11\%, Membutuhkan media pembelajaran yang dapat bergerak untuk meningkatkan motivasi belajar 74.02\%, Membutuhkan media pembelajaran yang berwarna-warni untuk meningkatkan antusias belajar dengan nilai rata-rata 77.32\%, Membutuhkan media pembelajaran yang berisi video untuk meningkatkan motivasi belajar 77.02\%, Membutuhkan media pembelajaran yang dapat diakses kapanpun untuk meningkatkan antusias belajar dengan nilai rata-rata 
Ta'Cim al-'Arabiyyah : Jurnal Pendidikan Bahasa Arab dan Kebahasaaraban, 5 (2), 2021

$79.00 \%$, Membutuhkan media pembelajaran yang dapat menyajikan materi pelajaran secara menarik untuk meningkatkan motivasi belajar dengan nilai rata-rata $76.39 \%$.

Berdasarkan nilai rata-rata tertinggi kebutuhan siswa kelas VIII A menunjukkan butir 9 dengan nilai presentase $79.00 \%$ (Dibutuhkan) yaitu membutuhkan media pembelajaran yang dapat diakses kapanpun untuk meningkatkan antusias belajar.

b. Kelas VIII B

Tabel 4. Hasil Angket Kebutuhan Siswa (Butir 1-5)

\begin{tabular}{ccccc}
\hline Butir 1 & Butir 2 & Butir 3 & Butir 4 & Butir 5 \\
\hline $63.39 \%$ & $65.35 \%$ & $65.68 \%$ & $60.94 \%$ & $59.31 \%$ \\
\hline
\end{tabular}

Tabel 5. Hasil Angket Kebutuhan Siswa (Butir 6-10)

\begin{tabular}{ccccc}
\hline Butir 6 & Butir 7 & Butir 8 & Butir 9 & Butir 10 \\
\hline $71.73 \%$ & $73.20 \%$ & $76.70 \%$ & $83.00 \%$ & $80.00 \%$ \\
\hline
\end{tabular}

Hasil angket kebutuhan siswa jika digambarkan pada grafik.

Grafik 3. Hasil Angket Kebutuhan Siswa (Butir 1-5)

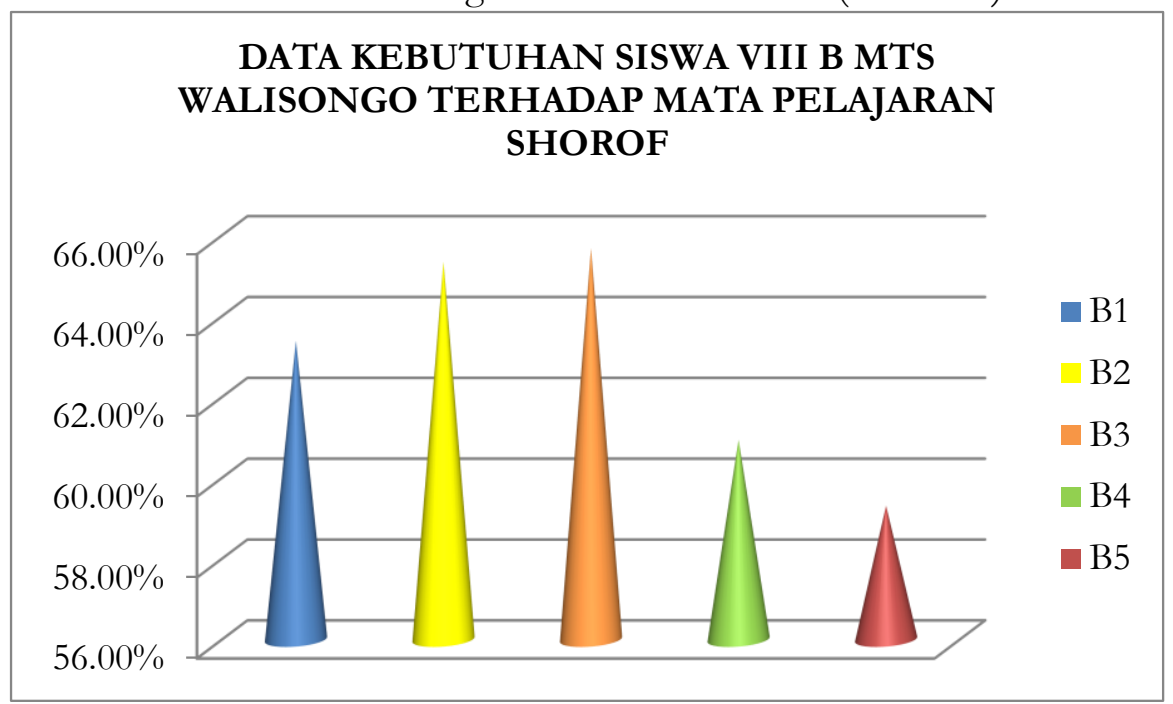

Grafik 4. Hasil Angket Kebutuhan Siswa (Butir 6-10) 


\section{DATA KEBUTUHAN SISWA VIII B MTS WALISONGO TERHADAP MATA PELAJARAN SHOROF}

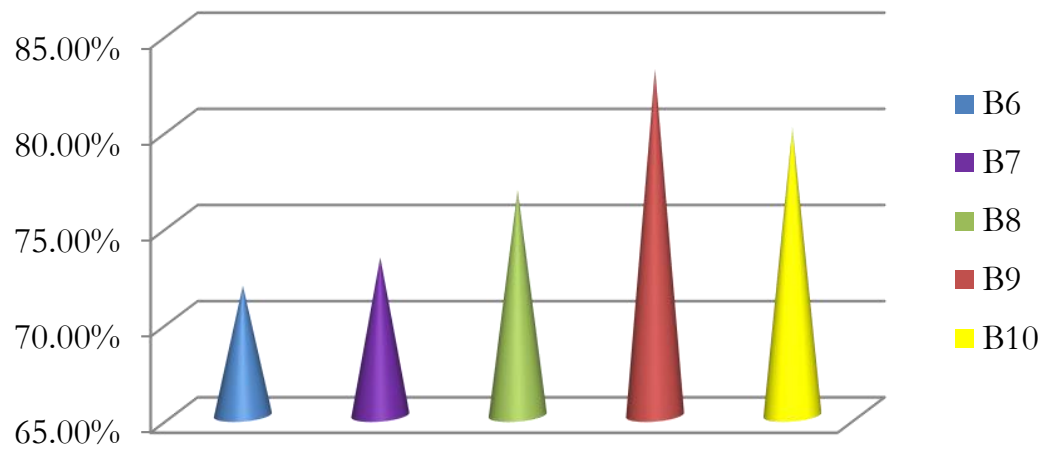

Dari data kebutuhan siswa kelas VIII B menunjukkan bahwa Sumber belajar berupa buku/LKS dirasa sudah cukup dengan nilai rata-rata 63.39\%, Antusias selama mengikuti pelajaran dengan nilai rata-rata $65.35 \%$, Termotivasi selama mengikuti pelajaran dengan nilai rata-rata $65.68 \%$, Materi pelajaran mudah dipahami dengan nilai rata-rata $60.94 \%$, Mengalami kesulitan dalam mempelajari materi pelajaran yang hanya bersumber pada buku/LKS dengan nilai rata-rata 59.31\%, Membutuhkan media pembelajaran yang dapat bergerak untuk meningkatkan motivasi belajar $71.73 \%$, Membutuhkan media pembelajaran yang berwarna-warni untuk meningkatkan antusias belajar dengan nilai rata-rata $73.20 \%$, Membutuhkan media pembelajaran yang berisi video untuk meningkatkan motivasi belajar $76.70 \%$, Membutuhkan media pembelajaran yang dapat diakses kapanpun untuk meningkatkan antusias belajar dengan nilai rata-rata $83.00 \%$, Membutuhkan media pembelajaran yang dapat menyajikan materi pelajaran secara menarik untuk meningkatkan motivasi belajar dengan nilai rata-rata $80.00 \%$. Berdasarkan nilai rata-rata tertinggi kebutuhan siswa kelas VIII B menunjukkan butir 9 dengan nilai presentase $83.00 \%$ yaitu membutuhkan media pembelajaran yang dapat diakses kapanpun untuk meningkatkan antusias belajar.

Diperoleh hasil nilai presentase tertinggi pada kelas VIII A dan kelas VIII B $83.00 \%$ (Sangat dibutuhkan) pada butir 9. Mengingat banyak siswa yang sudah memiliki smartphone sehingga menjadi alternatif sarana pembelajaran yang bisa diakses kapan saja. Media pembelajaran yang berupa microsoft power point bisa dimanfaatkan guru untuk menjadi media yang interaktif. Di dalamnya guru bisa menyampaikan pembelajaran dengan menarik mulai dari adanya animasi, video dan audio. Kemudian presentasi dari Microsoft power point bisa diubah menjadi flash yang berupa HTML sehingga siswa bisa mengaksesnya tanpa menggunakan data. Setelah itu dilanjutkan dengan memasukan file ispring suite tersebut ke dalam Web 2 Apk yang nantinya akan dijadikan aplikasi. Aplikasi ini selanjutnya bisa di install di smartphone, laptop atau tablet. 
Ta'Cim al-'Arabiyyah : Jurnal Pendidikan Bahasa Arab dan Kebahasaaraban, 5 (2), 2021

Adanya media pembelajaran ispring suite mempermudah guru agar menciptakan media yang kreatif serta dapat diakses kapan saja. Adanya fungsi ispring suite yang mampu dijadikan flash hingga aplikasi android membuat siswa bisa memanfaatkan smartphone untuk belajar. Jika digambarkan pada tabel kebutuhan siswa berdasarkan angket kebutuhan sebagai berikut

Tabel 6. Hasil Angket Kebutuhan Media Pembelajaran Shorof Kelas VIII A dan VIII B

\begin{tabular}{|c|c|c|c|}
\hline No & Kebutuhan Siswa & VIII A & VIII B \\
\hline 1 & $\begin{array}{l}\text { Sumber belajar berupa buku/LKS } \\
\text { dirasa sudah cukup }\end{array}$ & $\begin{array}{l}\quad 68.76 \% \\
\text { (Dibutuhkan) }\end{array}$ & $\begin{array}{c}63.39 \% \\
\text { (Dibutuhkan) }\end{array}$ \\
\hline 2 & $\begin{array}{l}\text { Antusias selama mengikuti } \\
\text { pelajaran }\end{array}$ & $\begin{array}{c}\quad 63.78 \% \\
\text { (Dibutuhkan) }\end{array}$ & $\begin{array}{c}\quad 65.35 \% \\
\text { (Dibutuhkan) }\end{array}$ \\
\hline 3 & $\begin{array}{l}\text { Termotivasi selama mengikuti } \\
\text { pelajaran }\end{array}$ & $\begin{array}{c}\quad 67.86 \% \\
\text { (Dibutuhkan) }\end{array}$ & $\begin{array}{c}65.68 \% \\
\text { (Dibutuhkan) }\end{array}$ \\
\hline 4 & $\begin{array}{l}\text { Materi pelajaran mudah dipahami } \\
\text { jika hanya lewat buku }\end{array}$ & $\begin{array}{c}63.27 \% \\
\text { (Dibutuhkan) }\end{array}$ & $\begin{array}{l}\text { 60.94\% } \\
\text { (Cukup } \\
\text { dibutuhkan) }\end{array}$ \\
\hline 5 & $\begin{array}{l}\text { Mengalami kesulitan dalam } \\
\text { mempelajari materi pelajaran yang } \\
\text { hanya bersumber pada buku/LKS }\end{array}$ & $\begin{array}{c}\text { 67.11\% } \\
\text { (Dibutuhkan) }\end{array}$ & $\begin{array}{l}59.31 \% \\
\text { (Cukup } \\
\text { dibutuhkan) }\end{array}$ \\
\hline 6 & $\begin{array}{l}\text { Membutuhkan media } \\
\text { pembelajaran yang dapat bergerak } \\
\text { untuk meningkatkan motivasi } \\
\text { belajar }\end{array}$ & $\begin{array}{l}74.02 \% \\
\text { (Dibutuhkan) }\end{array}$ & $\begin{array}{c}71.73 \% \\
\text { (Dibutuhkan) }\end{array}$ \\
\hline 7 & $\begin{array}{l}\text { Membutuhkan media } \\
\text { pembelajaran yang berwarna- } \\
\text { warni untuk meningkatkan } \\
\text { antusias belajar }\end{array}$ & $\begin{array}{c}77.32 \% \\
\text { (Dibutuhkan) }\end{array}$ & $\begin{array}{c}73.20 \% \\
\text { (Dibutuhkan) }\end{array}$ \\
\hline 8 & $\begin{array}{l}\text { Membutuhkan media } \\
\text { pembelajaran yang berisi video } \\
\text { untuk meningkatkan motivasi } \\
\text { belajar }\end{array}$ & $\begin{array}{c}77.02 \% \\
\text { (Dibutuhkan) }\end{array}$ & $\begin{array}{c}76.70 \% \\
\text { (Dibutuhkan) }\end{array}$ \\
\hline 9 & $\begin{array}{l}\text { Membutuhkan media } \\
\text { pembelajaran yang dapat diakses } \\
\text { kapanpun untuk meningkatkan } \\
\text { antusias belajar }\end{array}$ & $\begin{array}{c}79.00 \% \\
\text { (Dibutuhkan) }\end{array}$ & $\begin{array}{c}83.00 \% \\
\text { (Sangat } \\
\text { Dibutuhkan) }\end{array}$ \\
\hline
\end{tabular}


Ta'lim al-'Arabiyyah : Jurnal Pendidikan Bahasa Arab dan Kebahasaaraban, 5 (2), 2021

\begin{tabular}{llrcr}
\hline \multicolumn{3}{c}{ Membutuhkan } & \multicolumn{3}{c}{ media } & \\
pembelajaran $10 \quad$ yang & dapat & $76.39 \%$ & $80.00 \%$ \\
menyajikan materi pelajaran & (Dibutuhkan) & (Dibutuhkan) \\
secara $\quad$ menarik & untuk & & \\
meningkatkan motivasi belajar & & \\
\hline
\end{tabular}

Dari data di atas rata-rata siswa mengalami kesulitan dalam mempelajari materi pelajaran yang hanya bersumber pada buku/LKS. Ada data kebutuhan siswa yang tertinggi yaitu membutuhkan media pembelajaran yang dapat diakses kapanpun untuk meningkatkan antusias belajar pada kelas VIII A dengan nilai presentase $79.00 \%$ (Dibutuhkan) dan VIII B dengan nilai presentase 83.00\% (Sangat dibutuhkan).

\section{SIMPULAN}

Berdasarkan hasil kebutuhan siswa terhadap media ispring suite berbasis android pada mata pelajaran shorof yaitu membutuhkan media pembelajaran yang dapat diakses kapanpun untuk meningkatkan antusias belajar pada kelas VIII A dengan nilai presentase 79.00\% (Dibutuhkan) dan VIII B dengan nilai presentase $83.00 \%$ (Sangat dibutuhkan). Poin tersebut sudah terdapat pada media pembelajaran ispring suite berbasis android.

\section{DAFTAR PUSTAKA}

Budiyono. (2020). Inovasi Pemanfaatan Teknologi Sebagai Media Pembelajaran Di Era Revolusi 4.0. Jurnal Kependidikan, 6(2), 300-309.

Falahudin, I. (2014). Pemanfaatan Media Dalam Pembelajaran. Jurnal Lingkar Widyaiswara, 1(Desember), 104-117.

Mahnun, O. N. (2012). MEDIA PEMBELAJARAN ( Kajian terhadap Langkahlangkah Pemilihan Media dan Implementasinya dalam Pembelajaran ). Jurnal Pemikiran Islam, 37(1), 27-33.

Naseha, S. D., \& Muassomah, M. (2018). Model Pembelajaran Ilmu Sharaf Dengan Menggunakan Metode Inquiry Dan Metode Tashrif (di Jurusan Pendidikan Bahasa Arab UIN Maulana Malik Ibrahim Malang). Alfazuna, 3(Juni), 103-122.

Nurrita, T. (2018). Pengembangan Media Pembelajaran Untuk Meningkatkan Hasil Belajar Siswa. Misykat, 03(Juni), 171-187.

Purnama, S. (2013). Produk Pembelajaran Bahasa Arab. Literasi, 4(1), 19-32.

Ramadani, E. M. (2020). Media Pembelajaran Berbasis Aplikasi Android Menggunakan PowerPoint Ispring Suite 9 dengan Model POE2WE pada Materi Teori Kinetik Gas: Literature Review. Jurnal Pendidikan Fisika Tadolako Online (JPFT), 8(3), 79_ 86.

Sugiyono. (2019). Metode Penelitian Kuantitatif, Kualitatif dan R\&D. 